\title{
PENAMBAHAN PREBIOTIK OLIGOFRUKTOSA DAN ENZIM FITASE DARI Aspergillus niger PADA PAKAN YANG MENGANDUNG WHEAT POLLARD TERHADAP PERFORMA BROILER
}

\section{Addition of Prebiotic Oligofructose and Enzyme Phytase from Aspergillus niger in Feed Containing Wheat Pollard on Performance Broiler}

\author{
Suci Wulandari, Dadik Pantaya, Ujang Suryadi \\ Jurusan Peternakan, Politeknik Negeri Jember \\ Email: sucindariwulan21@gmail.com
}

\begin{abstract}
INTISARI
Penelitian ini bertujuan untuk mengetahui pengaruh penambahan prebiotik oligofruktosa dan enzim fitase dalam pakan yang mengandung wheat pollard terhadap performa broiler. Oligofruktosa ditambahkan dalam pakan sebanyak $2 \mathrm{~g} / \mathrm{kg}$ dan enzim fitase dengan dosis 500 $\mathrm{U} / \mathrm{kg}$. Parameter yang diuji adalah performa ayam pedaging. Seratus ayam broiler pada hari 14 sampai 28 dibagi menjadi 5 perlakuan yaitu: pakan dengan penambahan $\mathrm{P}$ dari dicalcium phosphate (P1), pakan kontrol (P2), pakan dengan penambahan oligofruktosa (P3), pakan dengan penambahan enzim fitase $2 \mathrm{~g} / \mathrm{kg}$ dari Aspergillus niger (P4), dan pakan dengan campuran penambahan oligofruktosa $2 \mathrm{~g} / \mathrm{kg}$ dan enzim fitase dengan dosis $500 \mathrm{U} / \mathrm{kg}$ (P5). Data dianalisis dengan Rancangan Acak Lengkap (RAL), jika terdapat perbedaan dilakukan uji lanjut dilanjutkan dengan Duncan's Multiple Range Test (DMRT). Hasil penelitian menunjukkan bahwa pemberian pakan yang mengandung $\mathrm{P}$ tinggi, penambahan oligofruktosa, pemberian enzim fitase, kombinasi antara oligofruktosa dan enzim fitase menunjukkan peningkatan performa broiler pada pemiliharaan 14 sampai 28 hari.
\end{abstract}

Kata kunci: Enzim Fitase, Performa Broiler, Oligofruktosa, Wheat Pollard

\begin{abstract}
This study was conducted to determine the effect of the addition of prebiotic oligofructose and phytase enzymes in feed containing wheat pollard on the performance of broiler. Oligofructose was added in feed $2 \mathrm{~g} / \mathrm{kg}$ and phytase enzyme dose $500 \mathrm{U} / \mathrm{kg}$. Parameters measured were broiler performance. One hundred broiler on 14 through 28 days were divided into 5 treatments: feed added P from dicalcium phosphate (P1), control feed (P2), feed added oligofructose (P3), feed added $2 \mathrm{~g} / \mathrm{kg}$ phytase enzyme from Aspergillus niger (P4), and feed added a combination of oligofructose $2 \mathrm{~g} / \mathrm{kg}$ and phytase enzyme dose of $500 \mathrm{U} / \mathrm{g}$ (P5). The data was analyzed to use Completely Randomized Design (CRD), if there was differences in further tests to be followed by Duncan's Multiple Range Test (DMRT). The results showed the feed containing high $P$, oligofructose addition, phytase enzyme, combination between oligofructose and phytase enzyme showed improvement of broiler performance on 14 to 28 days.
\end{abstract}

Keywords: Enzyme Phytase, Performance Broiler, Oligofructose, Wheat Pollard

\section{PENDAHULUAN}

Penggunaan antibiotik untuk menstimulasi pertumbuhan pada ternak telah banyak dipakai secara luas, tetapi penggunaan antibiotik akan menyebabkan meningkatnya resistensi terhadap penyakit tertentu dan menimbulkan dampak residu pada produk ternak. Oleh karena itu, penggunaan antibiotik mulai tahun 2005 dilarang di Uni Eropa dan 
Amerika. Bahan herbal saat ini banyak digunakan sebagai alternatif pengganti antibiotik.

Prebiotik merupakan salah satu bahan suplemen yang mempunyai kandungan polisakarida yang tidak terhidrolisis oleh enzim pencernaan dan hanya dibutuhkan dalam jumlah sedikit untuk menstimulasi perkembangan bakteri Bifidobacterium, Lactobaccilus, dan menghambat bakteri $E$. coli pada usus (Hidaka et al, 1991).

Jenis prebiotik yang banyak digunakan yaitu mananoligosakarida, oligofruktosa, dan galaktooligosakarida. Inulin merupakan polifruktosa yang dapat dikembangkan untuk memproduksi oligofruktosa. Oligofruktosa mengandung rantai linear $\beta$-D-fruktofuranose yang berikatan dengan 1,2 ikatan glikosidik (Monsan dan Poul, 1995).

Wheat pollard merupakan bahan baku pakan ternak yang mempunyai zat anti nutrisi (fitat) sehingga akan meningkatkan kebutuhan bahan fosfor anorganik yang akan meningkatkan biaya produksi. Fitat yang banyak terkandung pada biji-bijian dapat mengurangi ketersediaan mineral $\mathrm{P}$ (fosfor) dan Ca (kalsium) yang dapat diserap oleh saluran pencernaan. Kandungan fitat pada pollard sebanyak 4,21\%, hanya sekitar 60 sampai $80 \% \quad \mathrm{P}$ dari fitat yang dapat dimanfaatkan. Penambahan enzim fitase dapat meningkatkan kecernaan $\mathrm{P}$ dengan menghidrolisis ikatan fitat dan mengurangi penggunanan $\mathrm{P}$ anorganik. Mineral $\mathrm{P}$ dan $\mathrm{Ca}$ sangat berperan untuk pertumbuhan tulang, produksi telur (Yanuartono et al., 2017).
Penambahan prebiotik pada pakan yang mengandung $\mathrm{P}$ tersedia yang tinggi dapat meningkatkan performa produksi broiler. Penelitian ini bertujuan untuk mengetahui pengaruh penambahan prebiotik dan enzim fitase terhadap performa broiler.

\section{MATERI DAN METODE}

Sebanyak 100 ekor dibagi menjadi 20 kelompok pakan yang ditempatkan secara acak pada 5 perlakuan yaitu: pakan dengan penambahan $\mathrm{P}$ dari dicalcium phosphate (P1), pakan kontrol (P2), pakan dengan penambahan oligofruktosa (P3), pakan dengan penambahan enzim fitase $2 \mathrm{~g} / \mathrm{kg}$ dari Aspergillus niger (P4), dan pakan dengan campuran penambahan oligofruktosa $2 \mathrm{~g} / \mathrm{kg}$ dan enzim fitase dengan dosis $1.000 \mathrm{U} / \mathrm{kg}$ (P5). Setiap perlakuan terdiri dari 4 ulangan dengan 5 ekor setiap ulangan. Pakan dan air minum diberikan adlibitum. Pemberian pakan dilakukan selama 2 minggu mulai umur 14 sampai 28 hari pemeliharaan. Komposisi pakan uji penambahan oligofruktosa dan enzim fitase disajikan pada Tabel 1.

Performa ternak yang diamati meliputi: pertambahan bobot badan, konsumsi pakan, dan konversi pakan. Rancangan percobaan yang digunakan adalah Rancangan Acak Lengkap (RAL) pola searah. Apabila ada perbedaan yang nyata dilanjutkan uji DMRT (Steel dan Torrie, 1980). 
Tabel 1. Komposisi Pakan Uji Penambahan Oligofruktosa dan Enzim Fitase

\begin{tabular}{lcc}
\hline \multicolumn{1}{c}{ Bahan } & P Tinggi $^{1}$ & P Rendah $^{2}$ \\
\hline Jagung (\%) & 28 & 30 \\
Wheat pollard (\%) & 35 & 35,5 \\
Tepung ikan (\%) & 4 & 7,5 \\
Bungkil kedelai (\%) & 15 & 18 \\
Bekatul (\%) & 8 & 4 \\
Tepung daging (\%) & 6,5 & 6 \\
CPO (crude palm oil) (\%) & 1 & 1 \\
DCP (dicalcium phosphate) (\%) & 0,5 & - \\
CaCO (calcium carbonate) (\%) & 1 & 0,75 \\
Premiks dan vitamin ${ }^{1}(\%)$ & 1 & 1 \\
NaCl (\%) & 0,2 & 0,2 \\
\hline Komposisi pakan : & 3.000 & 3.000 \\
Energi metabolisme (kkal/kg) & 21 & 21,1 \\
Protein kasar (\%) & 5,22 & 4,8 \\
Lemak kasar (\%) & 3,19 & 3 \\
Serat kasar (\%) & 1,3 & 1,06 \\
Ca (calcium) (\%) & 0,93 & 0,82 \\
P Total (\%) & 0,53 & 0,4 \\
P tersedia (available P) (\%) & 1,3 & 1,3 \\
Lisin (\%) & 0,58 & 0,52 \\
Metionin (\%) & ( $\%$ ) & \\
\hline
\end{tabular}

1 Premik setiap kg mengandung: vit A, 9.000 1.17IU; vit D, 2.000 IU; vit E, 12 IU; vit B1, 0,5 mg; vit B6, $1 \mathrm{mg}$; niasin, $15 \mathrm{mg}$, asam pantotenat, 12,5 mg. Endox antioksidan, 100mg.

\section{HASIL DAN PEMBAHASAN}

Konsumsi pakan pada umur 14 sampai 21 hari terlihat tidak berpengaruh nyata terhadap semua perlakuan. Pada umur pemeliharaan 21 sampai 28 hari terlihat perbedaan yang nyata $(\mathrm{P}<0,05)$ dengan konsumsi paling rendah terdapat pada broiler dengan perlakuan enzim fitase (P4). Konsumsi pakan kumulatif broiler menunjukkan perbedaan yang nyata $(\mathrm{P}<0,05)$ dimana broiler yang diberi pakan kontrol mempunyai konsumsi pakan tertinggi. Konsumsi pakan dipengaruhi oleh banyak faktor diantaranya energi pakan, tinggi rendahnya fosfor dalam pakan, penambahan oligofruktosa dan enzim fitase.
Hasil penelitian (Tabel 2) menunjukkan perbedaan yang nyata $(\mathrm{P}<0,05)$ terhadap pertambahan bobot badan broiler pada pemeliharaan minggu pertama (14 sampai 21 hari). Pertambahan bobot badan broiler pada pemeliharaan minggu kedua (21 sampai 28 hari) menunjukkan perbedaan yang nyata $(\mathrm{P}<0,05)$ terjadi peningkatan bobot badan broiler jika dibandingkan dengan pakan kontrol yang mengandung $\mathrm{P}$ tersedia rendah. Pertambahan bobot badan broiler kumulatif (14 sampai 28 hari) menunjukkan perbedaan yang nyata $(\mathrm{P}<0,05)$ dengan ditunjukkan adanya peningkatan bobot badan broiler jika dibandingkan dengan pakan kontrol.

Konversi pakan pada pemeliharaan minggu pertama (14 sampai 21 hari) menunjukkan perbedaan yang nyata $(\mathrm{P}<0,05)$, 
hal ini terlihat dari nilai konversi pakan yang lebih rendah dibandingkan pakan kontrol. Konversi pakan pada pemeliharaan minggu kedua (21 sampai 28 hari) menunjukkan perbedaan yang nyata $(\mathrm{P}<0,05)$, nilai konversi pakan terendah terdapat pada pakan dengan perlakuan enzim fitase (P4). Konversi pakan kumulatif (14 sampai 28 hari) menunjukkan perbedaan yang nyata $(\mathrm{P}<0,05)$, dengan nilai konversi pakan terendah terdapat pada perlakuan dengan kandungan P tinggi (P1).

Tabel 2. Pertambahan Bobot Badan Broiler dengan Penambahan Oligofruktosa dan Enzim Fitase

\begin{tabular}{|c|c|c|c|c|c|c|}
\hline \multirow[b]{2}{*}{ Parameter } & \multicolumn{6}{|c|}{ Perlakuan } \\
\hline & $\begin{array}{c}\text { P Tinggi } \\
\text { (P1) }\end{array}$ & $\begin{array}{c}\text { Kontrol } \\
\text { (P2) }\end{array}$ & $\begin{array}{c}+ \text { OF } 2 g \\
\text { (P3) }\end{array}$ & $\begin{array}{c}\text { + Enzim Fitase } \\
500 \mathrm{U} / \mathrm{kg} \\
(\mathrm{P} 4)\end{array}$ & $\begin{array}{c}+\mathrm{OF}+\text { Enzim } \\
\text { Fitase } 500 \mathrm{U} / \mathrm{kg} \\
\text { (P5) }\end{array}$ & SEM \\
\hline \multicolumn{7}{|l|}{ Konsumsi } \\
\hline \multicolumn{7}{|l|}{ Umur } \\
\hline $14-21$ & 621 & 642 & 645 & 642 & 645 & 13 \\
\hline $21-28$ & $660^{\mathrm{ab}}$ & $687^{b}$ & $660^{\mathrm{ab}}$ & $653^{a}$ & $681^{\mathrm{ab}}$ & 21 \\
\hline $14-28$ & $1281^{\mathrm{a}}$ & $1330^{c}$ & $1305^{\mathrm{abc}}$ & $1296^{\mathrm{ab}}$ & $1326^{b c}$ & 25 \\
\hline \multicolumn{7}{|l|}{ PBB } \\
\hline \multicolumn{7}{|l|}{ Umur } \\
\hline $14-21$ & $357^{a}$ & $335^{b}$ & $353^{\mathrm{ab}}$ & $353^{\mathrm{ab}}$ & $354^{\mathrm{ab}}$ & 13 \\
\hline $21-28$ & $403^{a}$ & $372^{b}$ & $399 a$ & $409 a$ & $403^{a}$ & 16 \\
\hline $14-28$ & $760^{a}$ & $707^{b}$ & $753^{a}$ & $762^{\mathrm{a}}$ & $758^{\mathrm{a}}$ & 27 \\
\hline \multicolumn{7}{|l|}{ Konversi } \\
\hline Umur & & & & & & \\
\hline $14-21$ & $1,73^{a}$ & $1,92^{c}$ & $1,83^{b}$ & $1,82^{b}$ & $1,82^{b}$ & 0,07 \\
\hline $21-28$ & $1,63 \mathrm{a}$ & $1,63 \mathrm{~b}$ & $1,65^{a}$ & 1,59 a & 1,69 a & 0,1 \\
\hline $14-28$ & 1,68 a & $1,88^{c}$ & $1,73 \mathrm{ab}$ & $1,77 \mathrm{ab}$ & $1,75^{b}$ & 0,08 \\
\hline
\end{tabular}

OF : Oligofruktosa

SEM : Standart error mean

Huruf yang berbeda pada baris yang sama menunjukkan perbedaan yang nyata $(\mathrm{P}<0,05)$

Peningkatan pertambahan bobot badan tersebut disebabkan adanya peningkatan penyerapan asam amino untuk pertumbuhan. Penambahan oligofruktosa dan enzim mampu meningkatkan penyerapan mineral fosfor. Nila $\mathrm{pH}$ pada saluran pencernaan yang lebih asam menyebabkan terjadinya peningkatan kandungan P tersedia.

Kandungan $\mathrm{P}$ inorganik dapat ditingkatkan dengan adanya penambahan enzim karena hidrolisis enzim fitase terhadap kandungan fitat pakan. Fitase berpotensi menghidrolisis fitat pada $\mathrm{pH}$ netral dan rendah. Peningkatan kecernaan P pada pakan dengan penambahan enzim fitase juga dilaporkan oleh Ravindran et al. (2000) dan Ahmad et al. (2000) bahwa eksresi P pada pakan dengan kandungan $\mathrm{P}$ rendah menurun dengan penambahan fitase dan meningkatkan kecernaan P.

Penambahan oligofruktosa juga dapat mempengaruhi aktivitas enzim dalam saluran pencernaan, seperti yang dinyatakan oleh $\mathrm{Xu}$ et al. (2002) bahwa penambahan oligofruktosa dapat mempengaruhi sekresi 
enzim pencernaan dan akan meningkatkan aktivitas enzim amilase dan tripsin.

Fitat dapat juga mengikat protein dan menghambat aktivitas enzim tripsin dan pepsin (Caldwell, 1992). Penurunan nilai pH akan mempengaruhi kelarutan fitat yang akhirnya mempengaruhi enzim saluran pencernaan yaitu pepsin (Kirchgessner dan Roth, 1982). Selain dengan menggunakan penambahan prebiotik, penurunan $\mathrm{pH}$ juga dapat dikarenakan adanya penambahan asam organik antara lain asam sitrat dan asam askorbat pada pakan yang akan mampu menurunkan kandungan $\mathrm{P}$ tersedia (Afsharmanesh dan Poureza, 2005).

\section{KESIMPULAN}

Hasil penelitian menunjukkan bahwa pemberian pakan yang mengandung P tinggi, penambahan oligofruktosa, pemberian enzim fitase, kombinasi antara oligofruktosa dan enzim fitase menunjukkan peningkatan performa broiler pada pemiliharaan 14 sampai 28 hari.

\section{DAFTAR PUSTAKA}

Afsharmanesh M. and J. Pourreza. 2005. Effect of calcium, citric acid, ascorbic acid, vitamin D3, on the efficacy of microbial phytase in broiler starters fed wheat based diets. International Journal of Poultry Science. 4(6): 418-424.

Ahmad, T., S Rasool, M. Sarwar, A. Hq and H Zia-ul. 2000. Effect of microbial phytase from a fungus Aspergillus niger on bioavaibility of phosphorus and calcium in broiler chickens. Journal of Animal Feed Science Technology. 83(2): 103114.

AOAC. 1980. Official Methods of Analysis $14^{\text {th }}$ ed . AOAC. Washington DC. $1141 \mathrm{pp}$.

Caldwell, R.A. 1992. Effect of calcium and phytic acid on the activation of trypsinogen and the stability of tripsin. Journal of Agricutural and Food Chemistry. 40(1): 43-46.

Hidaka, H., M. Hirayama, T. Tokunaga, and T. Eida. 1991. The effect of undigestible fructooligosaccharides on intestinal microflora and various physiological function on human health. In New Development in Dietary Fiber (I. Furda, and C.J. Brine. Eds) pp 105-117. Plenum Press, New York , US.

Kirchgessner, M. and F.X. Roth. 1982. Fumaric acid as a feed additive in pig nutrition. Pig news information. 43(8): 253-263.

Monsan, P.F and F. Paul. 1995. Oligosaccaride feed additives. In Biotechnology in Animal Feeds and Animal Feeding. Edited Wallace, R.J and Chesson, A. VCH Publisher. Inc. New York USA.

Ravindran, V., S. Cabahug, P.H. Selle, and W.L. Bryden. 2000. Response of broiler chickens to microbial phytase supplementation as influenced by dietary phytic acid and non phytate phosphorus levels II. Effects on apparent metabolisable energy, nutrient digestibility and nutrient retention. British Poult Science. 41(2):193-200.

Steel, R.G.D. and Torrie, J.H. 1980. Principles and Procedures of Biostatistic. McGraw Hill New York, NY.

Xu, Z.R., Zou. X.T. Hu,C.H., Xia, M.S, Zhan, X.A and M.Q. Wang. 2002. Effect of Dietary Fructooligosaccharide on digestive enzyme activities, intestinal microflora and morphology of growing pigs. AsianAustralian Journal of Animal Sciences. 15(12): 1784-1789.

Yanuartono, A. Nururrozi, dan S. Indarjulianto. 2017. Fitat dan fitase: dampak pada hewan ternak. Jurnal Ilmu-Ilmu Peternakan. 26(3): 59 - 78. 